\title{
Ovalicin Ameliorates Compound 48/80-Induced Atopic Dermatitis-Related Symptoms
}

\author{
Cheol-Sik Yoon,${ }^{a, \#}$ Sung-Hee Nam,${ }^{b, \#}$ Ji-Young Jeon,${ }^{a}$ Hei-Sam LeE, ${ }^{b}$ Myeong-Lyeol LeE, ${ }^{b}$ \\ Hyeong-U SoN, ${ }^{c}$ and Sang-Han LEE ${ }^{*, c, d, e}$ \\ ${ }^{a}$ Mycoplus Co., Ltd.; Anyang 431-080, Korea: ${ }^{b}$ Department of Agricultural Biology, National Academy of Agricultural \\ Science; RDA, Suwon 441-100, Korea: ' ${ }^{c}$ Department of Food Science \& Biotechnology, Kyungpook National University; \\ ${ }^{d}$ Department of Nano-Science \& Technology, Kyungpook National University; and ${ }^{e}$ Department of Food \& Bio-Industry \\ Research Institute, Kyungpook National University; Daegu 702-701, Korea.
}

Received July 15, 2011; accepted September 21, 2011; published online September 28, 2011

\begin{abstract}
Ovalicin, a secondary metabolite produced by an entomopathogenic fungus Metarhizium anisopliae var. anisopliae, is currently used as an efficient biological control agent against various agricultural insect pests, but not so many biological activities have been investigated. To assess whether ovalicin has potential in ameliorating atopic dermatitis-related symptoms in mice, we first sensitized skin in the dorsal neck of Balb/c mice using compound $48 / 80$, and scrutinized whether the compound affected the atopic dermatitis-related symptoms. The results revealed that ovalicin significantly reduces scratching behavior in a concentration-dependent fashion. Moreover, the treatment inhibits the levels of the degranulation of mast cells by $65 \%$, and levels of histamine release by $51 \%$ at a concentration of $10 \mu \mathrm{g} / \mathrm{ml}$. Together, the present data strongly suggest that ovalicin elicits potential anti-atopic activities in mice.
\end{abstract}

Key words ovalicin; atopic dermatitis; scratching; degranulation; histamine

It is of great concern that recent allergic diseases-including atopic dermatitis, allergic rhinitis, asthma, allergic conjunctivitis, contact dermatitis, occupational allergies, and drug allergy have become prevalent over the last few decades, especially in infants and young children in developing countries. ${ }^{1)}$ These kinds of allergic symptoms may result from increasing industrial pollutants and environmental risk factors like antigens, endocrine disruptors, artificial foodstuffs, etc. Over the last several decades, the incidence of allergic diseases - especially atopic dermatitis - in developed countries has been constantly increasing 3-5 times; however, the treatment for such allergic diseases and their frequently-recurring symptoms are limited. ${ }^{2)}$

On the other hand, inflammation-related diseases - such as atopic dermatitis, allergic rhinitis and asthma-are considered chronic diseases caused by severe immune imbalances between Th1 and Th2 cell subsets. ${ }^{3)}$ It has now been revealed that some of all cytokines (IL-4, 10, 13, 25, 31, 32, 33) and chemokine receptors are associated with the balance of these two subsets of $\mathrm{T}$ cell lineage in atopic dermatitis. ${ }^{4}$ The activation of mast cells during immune stimulation requires several kinds of events, most of which happen successively in mast cells: 1) Fc receptor-mediated triggering, 2) an increase in intracellular calcium concentration and decreased levels of cAMP signaling via a process of degranulation of mast cells, and 3) histamine or mediator release. ${ }^{5)}$ A variety of signs and symptoms - vascular permeability, edema, itching, allergies, bronchial smooth muscle contraction - caused by the mediators released from mast cells then appear. ${ }^{6,7)}$ If we can estimate the expression profiles between the cells, this will result in a preventive remedy against atopic dermatitis that will be especially rewarding because at present there are few potent natural agents or other non-steroidal drugs.

The underlying mechanism for atopic dermatitis is still not clearly known. Temporary treatment with steroids and antihistamines relieves the symptoms, but the possibility of side effects still remains with these kinds of drugs. ${ }^{8)}$ Nevertheless, there are under researching on clinical efficacy test of chemicals or natural products. This research is guided by the activation of mast cells on atopic dermatitis-induced mast cells using a compound 48/80-induced mouse model in order to verify whether ovalicin has potential in ameliorating atopic dermatitis symptoms.

In the course of screening anti-allergic agents, we found that a culture broth from Metarhizium anisopliae var. anisopliae has potential activity against atopic dermatitis-related symptoms when we used a compound 48/80-induced animal model. We isolated and purified the active constituent and finally identified the compound as ovalicin. In this report, we investigate whether ovalicin ameliorates atopic dermatitis symptoms in vivo. To further confirm the decrease of atopic dermatitis symptoms, we isolated the mast cells from mice, and examined whether the granulation and histamine release are inhibited by ovalicin, because the granulation in mast cells is a hallmark of the infiltration process that develops during molecular inflammation events during atopic dermatitis development and results in secretion of histamine into the tissues.

\section{MATERIALS AND METHODS}

Materials and Chemicals HEPES-Tyrode buffer solution and $\mathrm{Ca}$-Locke solution were used for the in vitro assays. Compound 48/80 (Sigma Chemical Co., St. Louis, MO, U.S.A.) was dissolved in deionized water at a concentration of $50 \mu \mathrm{g} / \mathrm{ml}$. Mineral oil (Sigma Co., M5904) was used to solubilize ovalicin. All other chemicals were commercially available.

Culture and Purification Steps of Ovalicin The mycelium of Metarhizium anisopliae var. anisopliae was filtered by a filter paper (Whatmann No. 2). Culture was obtained by a liquid fermentation medium, thereafter preceded 
the separation and purification process. We designated the broth as MP108, which is explained in detail elsewhere for the medium composition and isolation, and for the purification of active component(s). ${ }^{9}$ In brief, the culture broth $(100 \mathrm{ml})$ was filtered, the resulting supernatant was extracted with ethyl acetate ( 2 times; v/v) in a $500 \mathrm{ml}$-flask. The combined solvent layers were concentrated with a vacuum evaporator to $20 \mathrm{ml}$ at $50{ }^{\circ} \mathrm{C}$; then $50 \mathrm{~g}$ of florisil (60-100 mesh) was added to adsorb the concentrated solvent layer. The adsorbed material was eluted into 4 fractions with 5 solvent systems (hexane : acetone $=100: 0,70: 30,20: 80$, and acetone: methanol $=80: 20,0: 100, \mathrm{v} / \mathrm{v})$ in a florisil-packed chromatography $(5.5 \times 50 \mathrm{~cm})$. Fractions from hexane: acetone $(20: 80, \mathrm{v} / \mathrm{v})$ and acetone : methanol $(80: 20, \mathrm{v} / \mathrm{v})$ systems exhibited relatively higher activity. Two fractions were combined and then re-eluted by hexane:acetone mixures $(100: 0,90: 10, \quad 70: 30, \mathrm{v} / \mathrm{v})$ and subsequently by acetone: methanol mixtures $(80: 20,20: 80,0: 100, \mathrm{v} / \mathrm{v})$. The highest activity was observed at the acetone: methanol $(20: 80, \mathrm{v} / \mathrm{v})$ fraction, which was then concentrated under a reduced pressure. The compound was analyzed by mass spectroscopy (Finnigan Mat Model 4510B; GC/MS) and a nuclear magnetic resonance (Varian Inova-300) analysis. After carefully interpreting the data, we finally determined that MP108 is ovalicin, based on 296.359 of molecular weight and carbon/proton ratio. To check whether or not to inhibit mast cell activation in vitro, we diluted ovalicin with dimethyl sulfoxide (DMSO) to various concentrations. At this point, the final concentration of DMSO was below $0.1 \%$.

Animals and Care Male Balb/c mice 6-7 weeks of age and weighing between $20-22 \mathrm{~g}$ were purchased from Samtaco (Osan, Korea). Animals were housed in an air-conditioned room at a temperature of $22 \pm 1{ }^{\circ} \mathrm{C}$ and a humidity of $65 \pm 5 \%$. All procedures were complied with the Guiding Principles for the Care and Use of Animals (National Research Council, 1996) and the guidelines of the Committee of the International Association for the Study of Pain's Research and Ethical Issues. ${ }^{10)}$ Animals were adapted to the laboratory environment for at least 1 week prior to experimentation. The number of mice in each experimental group was five.

Atopic Dermatitis Model and Measurement of Scratching Behavior In vivo atopic dermatitis model was used as described in elsewhere. ${ }^{11)}$ Induction was made by an injection of compound $48 / 80(50 \mu \mathrm{l}$ of $50 \mu \mathrm{g} / \mathrm{ml})$ in the mice's dorsal dermis. Mouse behavior was videotaped to check for either atopic dermatitis-like phenotypic features or symptoms. To test for anti-atopic symptoms, we applied each designated concentration of ovalicin $(0.06,0.6,6$, or $60 \mathrm{mg} / \mathrm{kg})$ to the mice's dorsal neck twice a day for $6 \mathrm{~d}$ (12 times overall). We measured the effect on symptoms by counting the number of times that the mice scratched their necks. Scratching behavior was recorded immediately after injection for 60 min. Designated concentrations of ovalicin were applied twice a day for $6 \mathrm{~d}$ before injection of compound 48/80.

Preparation of Mast Cells The preparation of mast cells was carried out by the Cochrane and Douglas method. $^{12)}$ In brief, rat peritoneal fluid $(10 \mathrm{ml})$ was obtained by collecting Ca-Locke solution $(150 \mathrm{~mm} \mathrm{NaCl}, 5 \mathrm{~mm} \mathrm{KCl}$, $2 \mathrm{mM} \mathrm{CaCl}_{2}, 1.0 \mathrm{mg} / \mathrm{ml}$ bovine serum albumin, $1.0 \mathrm{mg} / \mathrm{ml}$ glucose, $0.1 \mathrm{mg} / \mathrm{ml}$ heparin, $\mathrm{pH}$ 7.4) from the abdominal cav- ity after $90 \mathrm{~s}$ of massage. After 2 peritoneal washings, the upper suspension solution was discarded and re-suspended with Ca-Locke solution. In a $15 \mathrm{ml}$ centrifuge tube, $3.5 \mathrm{ml}$ of isotonic percoll solution ( $1 \mathrm{ml}$ of $10 \times$ Hank's solution plus $9 \mathrm{ml}$ of percoll) was mixed with $0.75 \mathrm{ml}$ of the re-suspended solution of mast cells and the Ca-Locke solution $(0.5 \mathrm{ml})$ was placed on the solution to centrifuge at $125 \boldsymbol{g}$ for $15 \mathrm{~min}$. Two $\mathrm{ml}$ of supernatant was removed by pipetting; additional washing was carried out at $4{ }^{\circ} \mathrm{C}$ for colleting a pure mast cell suspension.

Degranulation Measurement Mast cell suspension $(180 \mu \mathrm{l})$ stood for $10 \mathrm{~min}$ on the chamber. ${ }^{13)}$ To confirm whether ovalicin inhibits the compound 48/80-induced granulation of mast cells, various concentrations of ovalicin were pretreated with purified mast cells for $10 \mathrm{~min}$, and compound 48/80 treatment was successively carried out. Morphological changes were scrutinized under $1000 \times$ magnification.

Histamine Release Histamine release was carried out by the Harvima method (14) with a slight modification. ${ }^{14)}$ In brief, mast cells suspension $\left(10^{6}\right.$ cells $/ \mathrm{ml}, 180 \mu \mathrm{l}$ in Locke solution) was pretreated with either compound $48 / 80$ or various concentrations of ovalicin. The released histamine was measured by an enzyme-linked immunosorbent assay kit (IBL, IB89145, Mineapolis, MN, U.S.A.). ${ }^{15)}$

Statistical Analysis Data are presented as means \pm standard deviations. Statistical significance was determined by Dunncan's new multiple range test. ${ }^{16)}$ The critical level for significance was set at $p<0.05$.

\section{RESULTS AND DISCUSSION}

Ovalicin is a unique compound that is produced by an entomopathogenic fungus, Metarhizium anisopliae var. anisopliae. ${ }^{17-20)}$ The compound consisted of $\mathrm{C}_{16} \mathrm{H}_{24} \mathrm{O}_{5}$ with a molecular weight of 296.359, and showed anti-cancer, antifungal, anti-microsporidal, and anti-trypanosomal activities, ${ }^{21-23)}$ indicating that it has great potential for pharmaceutical application to various clinical fields. In initial purpose, we screened the isolate for an anti-inflammatory agent and purified it to identify the active compound as ovalicin. ${ }^{9}$ There are a few reports on ovalicin's characterization, identification, and biological activities, but this is the first report on its anti-atopic activity. At first we prepared mast cells from mice and measured cell cytotoxicity using an MTT assay kit (CT01, Millipore Korea, Daejeon, Korea). The cell survival rate was $92 \%$ at a concentration of $100 \mu \mathrm{g} / \mathrm{ml}$ on direct exposure, suggesting that ovalicin is not toxic to mast cells at the designated concentrations (data not shown). In this study, we examined whether ovalicin is an anti-atopic, and thus whether it has potential in treating dermatitis-related symptoms. By an atopic animal model that was induced by compound $48 / 80$, we counted how many times the mice scratched themselves, and calculated the inhibitory effect of ovalicin. As shown in Fig. 1, the normal mice did not scratch their necks at all, but exposure to compound 48/80 $(50 \mu \mathrm{g} / \mathrm{ml})$ significantly increased the number of scratches, which means the mice was fully induced to allergic (itching or pruritus) symptoms in their ears. The number of scratches peaked in $15 \mathrm{~min}$, showing a mean value of $42.0 \pm 3.5$. These values gradually decreased and became normal condition in $60 \mathrm{~min}$ (Fig. 1). However, ovalicin treatment $(0.1 \mu \mathrm{g} / \mathrm{ml})$ inhibited 
$21 \%$ after $15 \mathrm{~min}$ of exposure (Fig. 1). When we applied 1.0, 10 , or $100 \mu \mathrm{g} / \mathrm{ml}$ of ovalicin, the number of scratches dropped to around $34 \%, 50 \%$, and $74 \%$, respectively, compared with controls. Interestingly, the peaked time was delayed by the treatment of ovalicin up to $25 \mathrm{~min}$ to $35 \mathrm{~min}$ (Fig. 1, compare a-d). This result means that ovalicin affects anti-atopic symptoms by reducing, and by delaying the intensity or the number of scratches in a dose-dependent manner.

To further assess whether scratching behavior was decreased by ovalicin, we cut the tissues around the necks of the mice and prepared paraffin sections with hematoxylin and eosin staining to examine polymorphic nuclear leukocyte (PMNL) intrusion occurred, because the number of PMNL generally increases by the treatment of some allergens. The result showed that the PMNL induced by compound $48 / 80$

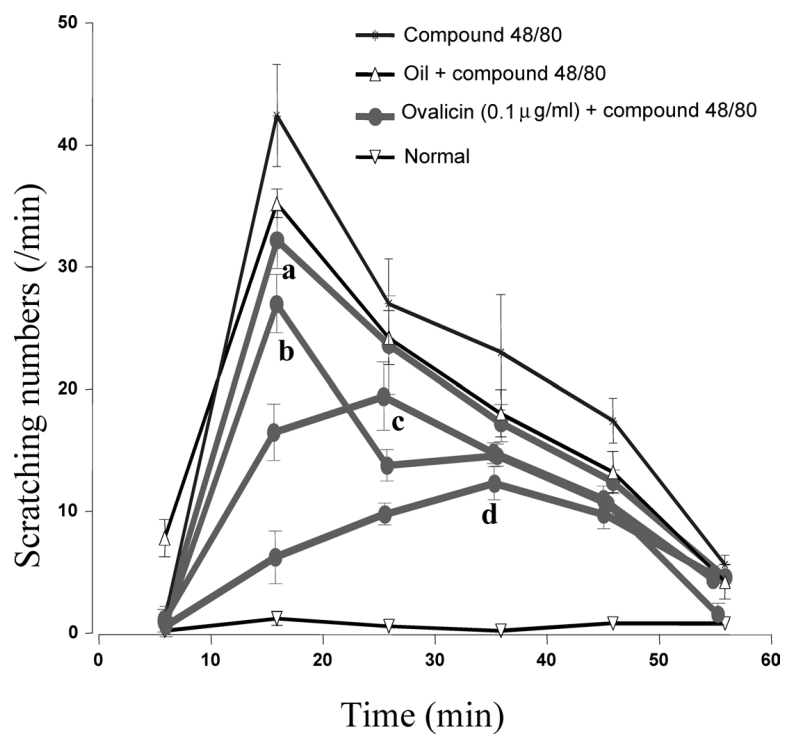

Fig. 1. Reduction Profile of Scratching Behavior by Ovalicin on Compound 48/80-Induced Atopic Dermatitis Model

Effect of ovalicin on compound 48/80-induced atopic signs. $\times$ : compound 48/80; $\triangle$ compound 48/80 plus mineral oil; $\nabla$ : normal; $\bullet$ : compound $48 / 80$ plus 0.1 (a), 1 (b) 10 (c), or 100 (d) $\mu \mathrm{g} / \mathrm{ml}$ of ovalicin. Data are presented as means \pm standard deviations of 5 mice. significantly decreased (data not shown). Again we stained the tissues with toluidine blue and measured the inhibition rate with a microscope to evaluate the granulated mast cells. As expected, the blue stained cells were largely absent in the ovalicin-treated tissues, showing that ovalicin inhibits formation of polymorphic nuclear leukocyte cells and granulated mast cells, which are known to play an important role in inflammation responses (data not shown).

It is well-documented that the activation of mast cells can be induced by 3 types: 1) immunoglobulin E cross-linking of Fc receptors in mast cells; 2) anaphylatoxins, such as $\mathrm{C} 3 \mathrm{a}$, C5a, etc.; or 3) pharmacological drugs or agents. Histamine, cell granules, proteolytic enzymes, heparin, or chemotactic factors are excreted from activated mast cells. ${ }^{24)}$ Thereafter, phospholipase A2 can trigger the secretion of newly-synthesized prostaglandins, leukotriens, or thromboxans. ${ }^{25)}$ Mediators released from mast cells variously result in induction of some or all of the followings: vascular permeability, edema, itching, allergies, bronchial smooth muscle contraction, and many other signs and symptoms. ${ }^{26}$ ) Therefore, we tested whether pretreatment of ovalicin has effect on inhibiting the activation of mast cells and how ovalicin affects some symptoms that can be deduced by measuring histamine contents and mast cell degranulation. Because these levels are critical hallmarks of mast cells' activation - and because T cell signals are transduced in mast cells-we measured the contents from the mast cells. The results showed that the treatment mitigated the levels of degranulation of mast cells by $65 \%$, and levels of histamine release by $51 \%$ at a concentration of $10 \mu \mathrm{g} / \mathrm{ml}$ (Figs. 2A, B), suggesting that ovalicin inhibited the granule formation from mast cells and the secretion of histamine.

In summary, the current results suggest that ovalicin has potential in ameliorating compound 48/80-induced atopic dermatitis symptoms, which we proved by reducing scratching behavior and by inhibiting degranulation of mast cells. Overall, it is interesting that the degranulation of mast cells and decrease of histamine release by ovalicin resulted in reducing atopic dermatitis-related symptoms, a discovery that may be applicable in the development of atopic dermatitisreducing or dermatitis-preventing therapies.
$\mathbf{A}$

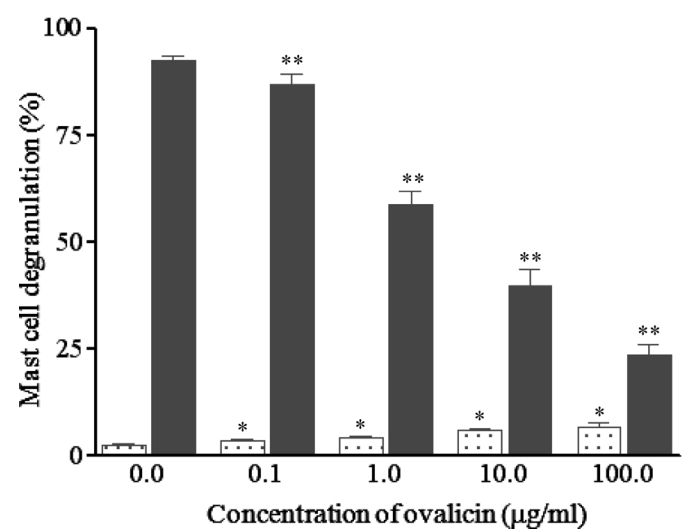

B

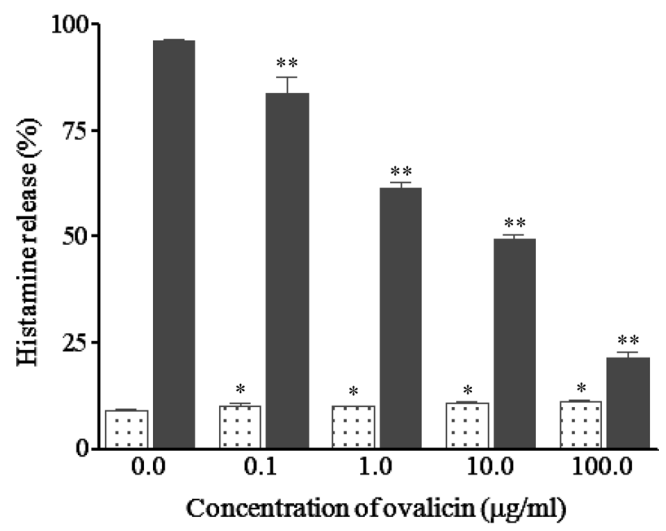

Fig. 2. Inhibitory Effects of Ovalicin on Compound 48/80-Induced Mast Cell Degranulation and Histamine Release in Mast Cells

(A, B), Degranulation (A) or histamine release (B) was measured as described in Materials and Methods by exhibiting relative inhibitory percentages of control and inhibitory histamine release of control, respectively. Data are presented as means \pm standard deviations of a classical feature of 3 independent experiments $(n=5)$. Dotted columns; controls, filled columns; compound 48/80-treated samples. * Significant difference from control, $p<0.05$; ** Significant difference from compound $48 / 80$-treated cells, $p<0.05$. 
Acknowledgment This work was supported by the BioGreen21 Agenda Project (PJ006701201004).

\section{REFERENCES}

1) Leung D. Y., Boguniewicz M., Howell M. D., Nomura I., Hamid Q. A., J. Clin. Invest., 113, 651-657 (2004).

2) Hanifin J. M., J. Invest. Dermatol., 129, 320-322 (2009).

3) Oyoshi M. K., He R., Kumar L., Yoon J., Geha R. S., Adv. Immunol., 102, 135-226 (2009).

4) Lewis D. B., Curr. Opin. Immunol., 14, 644-651 (2002).

5) Roth K., Chen W. M., Lin T. J., Arch. Immunol. Ther. Exp. (Warsaw), 56, 385-399 (2008).

6) Tokura Y., Röcken M., Clark R. A., Haliasos E., Takigawa M., Sinha A. A., Exp. Dermatol., 10, 128-137 (2001).

7) Ozdemir C., Akdis M., Akdis C. A., Chem. Immunol. Allergy, 95 $22-44$ (2010).

8) Chinen J., Shearer W. T., J. Allergy Clin. Immunol., 122, 36-41 (2008).

9) Yoon C. S., Park H. S., Korea Patent 0528033 (2005)

10) Charlton E., Committee on Ethical Issues of the International Association for the Study of Pain, Pain, 63, 277-278 (1995).

11) Orito K., Chida Y., Fujisawa C., Arkwright P. D., Matsuda H., Br. J. Dermatol., 150, 33-38 (2004).

12) Cochrane D. E., Douglas W. W., Proc. Natl. Acad. Sci. U.S.A., 71, $408-412$ (1974)
13) Na H. J., Jeong H. J., Shin H. Y., Kim N. S., Um J. Y., Hong S. H., Kim H. M., Int. Arch. Allergy Immunol., 139, 31-37 (2006).

14) Harvima R. J., Harvima I. T., Fräki J. E., Clin. Chim. Acta, 171, 247256 (1988).

15) Heo J. C., Park C. H., Lee H. J., Kim S. O., Kim T. H., Lee S.-H., Int J. Mol. Med., 25, 409-414 (2010).

16) Heo J. C., Park J. Y., Woo S. U., Rho J. R., Lee H. J., Kim S. U., Kho Y. H., Lee S.-H., Biol. Pharm. Bull., 29, 2256-2259 (2006).

17) Lazáry S., Stähelin H., Experientia, 24, 1171-1173 (1968).

18) Lazary S., Stähelin H., Antibiot. Chemother., 15, 177-181 (1969).

19) Kuboki H., Tsuchida T., Wakazono K., Isshiki K., Kumagai H., Yoshioka T., J. Antibiot., 52, 590-593 (1999).

20) Zimmermann W. A., Hartmann G. R., Eur. J. Biochem., 118, 143-150 (1981).

21) Selvakumar P., Lakshmikuttyamma A., Dimmock J. R., Sharma R. K. Biochim. Biophys. Acta, 1765, 148-154 (2006).

22) Cardenas M. E., Cruz M. C., Del Poeta M., Chung N., Perfect J. R. Heitman J., Clin. Microbiol. Rev., 12, 583-611 (1999).

23) Didier P. J., Phillips J. N., Kuebler D. J., Nasr M., Brindley P. J., Stovall M. E., Bowers L. C., Didier E. S., Antimicrob. Agents Chemother, 50, $2146-2155$ (2006)

24) Hakim-Rad K., Metz M., Maurer M., Curr. Opin. Allergy Clin. Immunol., 9, 427-430 (2009).

25) Balsinde J., Winstead M. V., Dennis E. A., FEBS Lett., 531, 2-6 (2002).

26) Pettigrew H. D., Teuber S. S., Kong J. S., Gershwin M. E., Clin. Rev. Allergy Immunol., 38, 125-134 (2010). 